\title{
Evigt liv till varje pris: En posthumanistisk tematisk studie av Don DeLillos roman Zero $K$
}

\section{Lotta Bergström}

I dag lever vi i en tid av snabb teknikutveckling. Nya upptäckter innebär att fler sjukdomar kan botas och att människor kan leva allt längre. Utökad kunskap om olika arters kognitiva förmågor i kombination med utvecklingen inom artificiell intelligens gör samtidigt att gränsen för vad som kan ses som mänskligt är på väg att bli mer diffus. Kanske är människan som art inte så exceptionell trots allt? Detta kan leda till att vi måste omdefiniera vår relation till den icke-mänskliga delen av världen (djur, natur och maskiner), och kanske kommer vi på sikt också att behöva ompröva vad det egentligen innebär att vara människa. Paradoxalt nog sammanfaller insikten om att den mänskliga exceptionalismen inte är självklar med att människan har intagit en särställning på ett nytt område. Detta då vi nu befinner oss i det som allt oftare benämns antropocen (människans tidsålder), den geologiska epok då mänskligt handlande har lett till betydande förändringar av geologi, klimat och ekosystem.

I följande artikel analyserar jag den amerikanske författaren Don DeLillos roman Zero K (2016). Det är en roman i vilken DeLillo utforskar ett aktuellt ämne: människans försök att med hjälp av modern teknik undkomma döden. Det här är ett tema som knyter an till vår tids utveckling inom bio-, gen- och nanoteknik. Analysen är tematiskt inriktad då det är romanens trans- och posthumanistiska teman som fokuseras. Syftet är dels att undersöka hur dessa teman representeras i romanen, dels att se hur de kan sammankopplas med romanens samhällskritiska inslag. Artikeln tar avstamp i en posthumanistisk teoribildning, det vill säga teorier som på olika sätt problematiserar och diskuterar den mänskliga existensens förändrade villkor till följd av bland annat den senmoderna teknikutvecklingen.

Zero K kom ut så sent som 2016, varför det än så länge är ont om analyser av den. Don DeLillos författarskap i övrigt är dock väl genomforskat. Jag har valt att i första hand använda texter ur antologin The Cambridge Companion to Don DeLillo (2008), eftersom där finns användbara exempel på tematiska angreppssätt på DeLillos verk. Jag har också använt Mark Osteens American Magic and Dread: Don DeLillo’s Dialogue with Culture (2000), då dess fokus på DeLillos samhällskritik tangerar syftet med min analys.

När det gäller posthumanistisk teori har jag bland annat använt mig av Rosi Braidottis The Posthuman (2013), N. Katherine Hayles How We Became Posthuman: Virtual Bodies in Cybernetics, Literature and Informatics (1999) och Cary Wolfes What Is Posthumanism? (2010). Redogörelsen för transhumanismen är primärt hämtad från Nick Bostroms ”A History of Transhumanist Thought” (2005), men även texter ur antologin The Transhumanist Reader (2013) har använts. I den senare medverkar flera av transhumanismens förgrundsgestalter, såsom Max More, den redan nämnda Bostrom och Natasha Vita-More.

Exempel på posthumanistiska litteraturanalyser finns i de redan berörda How We Became Posthuman och What Is Posthumanism?, men också i Mads Rosendahl Thomsens The New Human in Literature: Posthuman Visions of Changes in Body, Mind and Society after 1900 
(2013), Marie Öhmans Det mänskligas natur: posthumanistiska perspektiv hos Lars Jakobson, Peter Høeg och Kerstin Ekman (2015) och Jonas Ingvarssons En besynnerlig gemenskap: teknologins gestalter i svensk prosa 1965-70 (2003). Nyligen utkom också antologin The Cambridge Companion to Literature and the Posthuman (2017) med Bruce Clarke och Manuela Rossini som redaktörer.

\section{Don DeLillo och Zero K}

Don DeLillo (f. 1936) ses i dag som en av USA:s mest betydande författare. Han är kanske allra mest känd för sina skildringar av det postmoderna USA, där samtidskultur och -historia står i fokus. Han har emellertid i flera tidigare romaner berört teman som kan ses som posthumanistiska, som till exempel bioteknik och cyberkultur (Rosendahl Thomsen 2013: 187). Ofta kombinerar DeLillo det litterära med det samhällskritiska. Han utmärker sig ibland också genom att kommentera och diskutera företeelser och tendenser i samhället, innan dessa ens har aktualiserats. Till exempel diskuterar han i Players (1977) och i Mao II (1991) terrorism på sätt som kommit att ses som relevanta i efterdyningarna av attackerna den 11 september 2001 (Duvall 2008: 1-2).

I Zero $K$ fokuseras framstegen inom bio-, nano- och diverse annan teknik, och hur människor förhåller sig till denna utveckling. Ett ofta återkommande tema hos DeLillo är döden, och människans förhållande till sin egen dödlighet. I White Noise (1985) går protagonisten Jack Gladney och hans hustru Babette så långt att de prövar ett experimentellt och potentiellt livsfarligt läkemedel för att komma över skräcken för döden. I Zero $K$ är det inte längre dödsskräcken, utan döden själv som ska besegras. Ett annat återkommande tema hos DeLillo är språket. Redan i början av 1970-talet ska DeLillo ha sagt att han ser språket både som ett ämne för hans författarskap och som det verktyg han använder sig av (Cowart 2008: 151). I Zero K tematiseras språk genom att ett artificiellt språk är en del i skapandet av en ny sorts människa. Även språkets meningsskapande funktion är ett tema i romanen.

Zero $K$ utspelar sig till stor del i anläggningen the Convergence, någonstans i öknen i södra Kazakstan. The Convergence präglas av anonymitet och otillgänglighet. Hit kommer välbeställda människor som vägrar acceptera sin egen dödlighet. Romanens protagonist är Jeff, den drygt 30-åriga sonen till mångmiljardären Ross Lockhart. Jeff är också romanens berättare och fokalisator. Trots det futuristiska anslaget utspelar sig Zero K i nutid. Texten består av två delar, "In the Time of Chelyabinsk” och "In the Time of Konstantinovka”. Den första delens titel anspelar på den meteorit som exploderade över den ryska staden Tjaljabinsk 2013, och den andra på kravaller i östra Ukraina 2015.

I del ett beger sig Jeff till the Convergence för att ta farväl av sin döende multisjuka styvmor Artis. Hon står inför att låta sig frysas ned och placeras i en underjordisk kapsel, för att kunna väckas till liv i en avlägsen framtid, då hennes många sjukdomar förhoppningsvis ska kunna botas. Trots att Ross är fullt frisk bestämmer han sig för att följa med Artis, vilket i praktiken innebär ett slags assisterat självmord. Ross misslyckas emellertid med sin föresats, och lämnar the Convergence tillsammans med Jeff. Romanens andra del inleds två år senare i New York. Jeff har då en flickvän, Emma, men har fortfarande svårt att hitta sin plats i tillvaron. Ross försöker komma över att han inte klarade att fullfölja sitt beslut att ta avsked av livet och följa med Artis. Han är en bruten man, både på grund av sorgen och att det egna 
modet svek honom. Under de två år som gått har han avvecklat sitt imperium, och i slutet av romanen återvänder Jeff och Ross till the Convergence. Den här gången verkställer Ross sitt beslut och säger adjö inte bara till sin son, utan också till livet i den form han hittills känt det. En dag försvinner Emmas adoptivson Stak. När det fortfarande är oklart vad som har hänt honom får Jeff se honom dö på en videoinstallation hos the Convergence.

\section{Teoretiska utgångspunkter}

Det post- och transhumanistiska fältet är snårigt och mångfasetterat, med en uppsjö av begrepp som av olika teoretiker och inriktningar används på olika, i vissa fall motsägelsefulla sätt. Hur relationen mellan post- och transhumanism exakt ser ut råder det delade meningar om. Jag har valt att se transhumanismen som en av många varianter av det posthumanistiska tänkandet, då det handlar om -ismer som förvisso betraktar världen på skilda sätt och dessutom har olika mål, men som ändå förenas av intresset för såväl interaktionen människa/teknik som problematiserandet av relationen till humanismen. Det handlar i båda fallen om ett tänkande bortom humanismen som Robert Ranisch och Stefan Lorenz Sorgner uttrycker det (2014: 7).

De flesta posthumanismerna (mångfalden gör att det är bättre att tala om -ismer än om en specifik -ism) förenas av att de problematiserar och ifrågasätter tanken om en människocentrerad världsordning och teoretiserar kring människans förhållande till det ickemänskliga, som teknik, djur och miljö. I detta ingår en uppvärdering av det materiella, ett erkännande av att människan, precis som det icke-mänskliga, inte bara är en konstruktion, utan också en kropp. Även djur- och miljörätt kan kopplas till posthumanismen, eftersom man där ifrågasätter en världsordning med människan i centrum. När det gäller posthumanism och djurrätt har framförallt Cary Wolfe utvecklat det teoretiska tänkandet (2010).

Det är omöjligt att överblicka det posthumanistiska fältet inom ramen för en artikel av det här omfånget, och det är heller inte nödvändigt. Jag begränsar mig därför till att redogöra för de delar av den posthumanistiska teoribildningen som är relevanta för analysen av romanen. Det innebär att fokus hamnar på två delar som kan ses som ytterligheter: transhumanismen och den kritiska posthumanismen. Transhumanismen är central för analysen eftersom den verksamhet som bedrivs i the Convergence är transhumanistisk, vilket jag kommer att återkomma till längre fram. Den kritiska posthumanismen är relevant för analysen, då det är med hjälp av den jag belyser de samhällskritiska inslagen i Zero K. När begreppet posthuman används i analysen syftar det i första hand på det posthumana tillståndet, det vill säga en tid då relationen mellan det mänskliga och det icke-mänskliga är stadd i förändring. Används begreppet på annat sätt förklaras det i texten.

Alla posthumanismer förenas av att de, om än på olika sätt, relaterar till humanismens antropocentriska världsbild. Idén om människans särställning utgår från en normativ syn på människans väsen, det vill säga att det finns en specifik okränkbar kärna av mänsklighet. Föreställningen om människans exceptionalism härleds ofta ur filosofen Renèe Descartes (1596-1650) resonemang om förnuftet som utmärkande för människan. Enligt Descartes är existensen indelad i två system, ett kroppsligt och materiellt och ett själsligt och ickemateriellt där den fria viljan styr. Här finns grunden till dualismen mellan kropp och själ. 
Enligt Descartes är det bara människan som är någonting utöver kropp. Djur och natur hör bara till den kroppsliga, materiella sfären. Människan är unik som den enda som är mer än kropp, vilket är ursprunget till idén om människans överordnade ställning (Öhman 2015: 2428). Humanismen är till viss del född ur sekulära upplysningstankar, där den cartesianska dualismen är grunden för att människan, med hjälp av sitt förnuft ska kunna ta sig rätten att utvecklas, även om det sker på bekostnad av djur och natur (Wolfe 2010: xvii). Den kritiska posthumanismen kan ses som en reaktion mot ovan nämnda delar av humanismen, medan transhumanismen i stället kan ses som en fortsättning på, eller som Wolfe formulerar det en intensifiering av dem (2010: xv).

\section{Kritisk posthumanism}

Jag har valt att betrakta all posthumanism som utgår ifrån antihumanismens subjektskritik och som också ser positiva möjligheter i det posthumana, det vill säga att posthumanismen kan utmana humanismens antropo- och androcentriska världsbild genom att öppna för nya typer av subjektsblivande, som kritisk posthumanism. Hit räknar jag bland andra teoretiker som Rosi Braidotti, N. Katherine Hayles och Cary Wolfe. Även Donna Haraway kan räknas hit, trots att hon i dag inte kallar sig posthumanist (Haraway 2008: 19).

Begreppet posthumanism myntades 1977 av litteraturteoretikern Ihab Hassan när han i "Prometheus as Performer: Toward a Posthumanist Culture?”, ifrågasätter många av humanismens klassiska dikotomier som natur/kultur, människa/teknik och kvinnligt/manligt (Hassan 1977: 839). Hassans resonemang har flera beröringspunkter med den kontinentala filosofins antihumanistiska kritik under 1960- och 1970-talen, då tänkare som Michel Foucault och Louis Althusser ifrågasatte humanismens tankar om det enskilda subjektets frihet och rationalitet (Åsberg 2012: 9). I The Order of Things kritiserar Foucault humanismen för dess arroganta sätt att placera människan i världsalltets mittpunkt, och utropar människans nära förestående död (Foucault 2005: 422).

Dagens kritiska posthumanism är delvis född ur denna antihumanistiska hållning. Braidotti skriver att kärnan i den kritiska posthumanismen utgörs av antihumanismen tillsammans med olika sociala rörelser som feminism, antikolonialism och antirasism. Dessa förenas av att de alla väckt frågan om vem som egentligen inkluderas i humanismens föreställning om det mänskliga subjektet, då detta som regel har varit den vita, europeiska mannen (Braidotti 2013: 16ff). Ur antihumanismens kritik av humanismen anser Braidotti att det i dag har vuxit fram ett mer positivt synsätt där möjligheterna med det posthumana subjektet betonas. Genom en dekonstruktion av humanismens antropo- och androcentriska subjekt kan det födas ett nytt sorts subjekt som är tillgängligt för fler. Detta kan öppna för fler sätt att vara människa (Braidotti 2013: 49). Posthumanistisk teori är för Braidotti också ett verktyg för att hitta nya, nödvändiga sätt att förhålla oss till oss själva och livet i antropocen, den tid då människan har blivit en kraft som påverkar alla former av liv på jorden (Braidotti 2013: 5).

En annan del av posthumanismen har sitt ursprung i teknikutvecklingen, och där brukar de så kallade Macy-konferenserna som tog sin början under 1940-talet ses som en startpunkt. Där uppstod den så kallade cybernetiken, det vill säga studiet av kommunikation och kontroll mellan såväl levande varelser som maskiner. Ur detta föddes ett nytt sätt att, i vissa kretsar, se människan som primärt: "information-processing entities who are essentially similar to 
intelligent machines” (Hayles 1999: 7). Hayles diskuterar hur en begreppslig upplösning mellan människa och teknik kan frammana en ny slags subjektivitet, där det mänskliga livet ses som en del av en materiell och komplex verklighet, som vi på alla sätt är beroende av för vår fortlevnad. Hon utgår, precis som Braidotti, från Hassans och Foucaults kritik av humanismens antropo- och androcentriska subjekt, och har också beröringspunkter med Donna Haraways biopolitiska resonemang om den mänskliga cyborgen som ett sätt att överskrida, framförallt genuskodade, begränsande normer (Haraway 2004).

Gemensamt för kritiska posthumanister är att de ser en positiv kraft i den posthumanistiska utvecklingen. Samtidigt som vår senmoderna tid består av utmaningar av vitt skilda slag, bland annat miljömässiga och etiska, innehåller den också möjligheter att genom nya sätt att tänka skapa en ny sorts mänskliga subjekt. Viktigt att notera är att kritiska posthumanister inte ser den politiska humanismens tankar om rättvisa och demokrati som överspelade, utan att de anser att ett posthumanistiskt synsätt bättre kan förverkliga dessa idéer än vad den klassiska humanismen har kunnat.

\section{Transhumanism}

En gren på det posthumanistiska trädet som inte tar avstånd från humanismen är transhumanismen. Här finns ingen kritik av humanismens människoessentialism, utan i stället ser man teknikutveckling som ett sätt att ytterligare utveckla människan. Där den kritiska posthumanismen strävar efter en ny mer inkluderande definition av vad det är att vara människa, vill transhumanismen rent fysiskt skapa en ny sorts människa.

Precis som flera posthumanistiska inriktningar fokuserar transhumanismen på relationen mellan människa och teknik, men perspektivet är radikalt annorlunda. Det är en modern filosofisk inriktning som av sina anhängare ses som en fortsättning på humanismens förnuftsoch framstegstro (Bostrom 2005: 2). Där humanismen utgår från mänsklig utveckling som en följd av kulturell utveckling och utbildning, vill transhumanismen med teknikens hjälp övervinna vad man beskriver som begränsningar till följd av vårt genetiska och biologiska arv (More 2013: 4). Även om det finns stora variationer mellan transhumanismens olika inriktningar förenas de alla av tron på både möjligheten och önskvärdheten i att tekniskt förbättra, eller förstärka den mänskliga kroppen (Ranisch och Sorgner 2014: 13). För transhumanister är det närmast självklart att det är en mänsklig uppgift att använda teknik för att göra människan smartare, starkare och mer långlivad. Här ses en teknisk utveckling som tänks kunna ge oss om inte evigt liv så i alla fall avsevärt förlängd livstid, men också högre intelligens och förbättrade kognitiva förmågor, som en fortsättning på upplysningens tankar om mänsklig utveckling (Dickel och Frewer 2014: 124ff).

Sedan 1998 samlas världens transhumanister i det som först hette The World Transhumanist Association, men som numera är omdöpt till Humanity+. Organisationen grundades i syfte att förena olika typer av transhumanistiska inriktningar, men ambitionen var också att utveckla en mer akademisk och trovärdig transhumanism (Bostrom 2005: 12).

Transhumanism är en idétradition som skiljer sig markant åt från kritisk posthumanism. Där kritisk posthumanism vill förändra vem som omfattas av det mänskliga och samtidigt öppna för ett mer etiskt förhållningssätt gentemot det icke-mänskliga håller transhumanismen fast vid den cartesianska dualismen, där människan ses som väsensskild från det icke- 
mänskliga. Samtidigt finns också inom transhumanismen en tro på att tekniska framsteg i sig ska lösa många av världens problem, såsom fattigdom och miljöförstöring (Kurzweil 2013: 451). Det sägs emellertid väldigt lite om hur exakt detta ska gå till.

\section{Litteratur, posthumanism och teknikutveckling}

Exakt vilken riktning en posthuman utveckling kommer att ta kan knappast förutsägas, men i litteraturen kan olika tänkbara vägar utforskas (Rosendahl Thomsen 2013: 11). Hayles framhåller att relationen mellan teknikutveckling och litteratur på många sätt är flerdimensionell. I litteraturen gestaltas redan befintlig teknik, men de litterära texterna är inte bara passiva förmedlare, utan formar aktivt vad vetenskapliga teorier och teknik betyder i en kulturell kontext, och det är också i litteraturen som etiska frågor kan prövas. Precis som litteratur kan formas av nya uppfinningar kan uppfinningar drivas fram av skönlitterära skildringar, då det finns gott om forskare inom det tekniska fältet som har inspirerats av skönlitterära texter (Hayles 1999: 21). Isaac Asimovs robotiklagar som han formulerade i novellen "I, Robot” (1950) har länge varit vägledande inom robotikforskningen, även om Braidotti påpekar att de i dag är i behov av uppdatering (Braidotti 2013: 43).

Litterära verk, och delar av dem, kan också fungera som metaforer för existerande samhällstillstånd eller fruktade framtida utvecklingar. När det gäller att diskutera kommande biotekniska genombrott är det ofta Aldous Huxleys Brave New World (1932) som är i fokus. Statsvetaren Francis Fukuyama utgår till exempel helt från Huxleys roman när han i Our Posthuman Future (2002) varnar för bio- och genteknikens konsekvenser: "The aim of this book is to argue that Huxley was right, that the most significant threat posed by contemporary biotechnology is the possibility that it will alter human nature and thereby move us into a 'posthuman' stage of history” (Fukuyama 2002: 7). Relationen mellan litteratur och modern teknikutveckling är således komplex och går i flera riktningar.

\section{Analys}

I Zero $K$ finns åtskilliga teman som knyter an till relationen mellan människa och teknik i en posthumanistisk kontext. Till det som sticker ut hör emellertid döden, i och med att verksamheten i the Convergence syftar till att med teknikens hjälp skapa en sorts evigt liv för de som så önskar och som har tillräckligt med kapital. Ett annat framträdande tema är att de individer som låter sina kroppar bevaras kryoniskt också upplåter kroppar och medvetanden åt de ansvariga, att forma och förändra efter behag. I en avlägsen framtid ska de inte återuppväckas som desamma som de var när de blev nedfrysta, utan som någonting annat, som en ny sorts människor. Detta tema går att förankra i den transhumanistiska visionen om att människan med hjälp av tekniken inte bara ska fortsätta att ständigt utvecklas, utan också förändras till någonting bättre. Eftersom dessa två teman är övergripande delas analysen in i två delar, där den första behandlar skapandet av en ny människa och den andra döden. Språket tematiseras i romanen både i relation till den nya människan och till döden, och behandlas därför i båda avsnitten. 


\section{Att skapa en ny människa}

Människorna som står bakom the Convergence har en transhumanistisk agenda, vilket innebär att de vill besegra döden och samtidigt skapa en mer utvecklad människa. De ser teknik som en central del i mänsklighetens framtida utveckling (Bostrom 2005: 21). I anläggningen i den kazakiska öknen är ambitionen inte bara att bidra till mänsklighetens utveckling, utan man vill också: "stretch the boundaries of what it means to be human stretch and then surpass. We want to do whatever we are capable of doing in order to alter human thought and bend the energies of civilization” (DeLillo 2016: 71) . ${ }^{1}$

Att vilja skapa en ny människa är ingen ny idé, även om det är förhållandevis nytt att det rent tekniskt går att göra det. Visioner om mänsklig förändring är inte en konsekvens av teknikutvecklingen, utan det är tankar som har lockat människor också förr (Rosendahl Thomsen 2013: 34). Enligt idéhistorikern Bosse Sundin var det 1200-talets upptäckt att det går att korrigera dålig syn med hjälp av slipat glas som gav upphov till föreställningar om att det går att med hjälp av teknik förbättra det av naturen givna (Sundin 2006: 132).

Rosendahl Thomsen delar in den moderna tidens tänkande kring den nya människan i tre olika faser. Den första sträcker sig ungefär från 1880-talet till 1930-talet. Då fanns en vilja att omforma sättet att tänka, som en konsekvens av evolutionsteorin och den tilltagande sekulariseringen. Den andra fasen, som sträcker sig från 1920-talet till slutet av det kalla kriget, handlade i stället om att skapa nya människor genom politiskt kontrollerade, radikala samhällsomvandlingar. Den tredje fasen som inleddes på 1970-talet är den vi nu befinner oss i. Här ligger fokus främst på biotekniska förändringar (Rosendahl Thomsen 2013: 34-35). Den fas som hittills har påverkat mänskligheten mest är den andra, eftersom: "the idea of a new human created through societal change was a part of movements responsible for making millions of people suffer and die” (Rosendahl Thomsen 2013: 37). Alla tre faser har paralleller i Zero $K$.

De som reser till the Convergence för att dö, lämnar inte bara sina kroppar och sina medvetanden till en oviss förvaring inför en framtida återfödelse, utan de upplåter sig också åt tekniker och ideologer som kommer att omskapa kroppar och medvetanden, så att dessa kan bli delar av en framtida ny sorts mänsklighet. "They will be subjects for us to study, toys for us to play with” (72), som en av ledarna uttrycker det.

Det kan tyckas märkligt att människor frivilligt vill överlämna sig, eller ens sina kvarlevor, till någonting så ovisst, men de flesta inblandade framstår som övertygade anhängare av den ideologi som genomsyrar the Convergence. Kanske handlar det om att vilja kontrollera sitt eget öde. Miljardären Ross som har skapat sin enorma förmögenhet genom att analysera vinstgenererande effekter av naturkatastrofer, ser det inte som ett alternativ att inte kunna kontrollera döden. Romanens första mening, vilken också uttalas av Ross är: ”[e]verybody wants to own the end of the world” (3). Även om han inte fullt ut kan kontrollera hur hans kropp och hans medvetande används efter hans död, ger hans starka tro på projektet som sådant också en tro på att han faktiskt äger sitt eget slut. Artis tror uttryckligen på en framtid som en ny sorts människa: ”I will become a clinical specimen. Advances will be made

\footnotetext{
${ }^{1}$ Fortsättningsvis kommer endast sidnummer att anges vid hänvisningar till DeLillos roman Zero K (2016).
} 
through the years. Parts of the body replaced or rebuilt. [...] A reassembling atom by atom” (47). Hennes situation är emellertid annorlunda än den hennes make befinner sig i. Hon vet att hon ändå kommer att vara död inom en mycket snar framtid. Detta gör att hennes val mer kan betraktas som ett val av gravplats, där ett alternativ, the Convergence, innebär hopp om att även efter döden få vara en del av framtiden.

Även om det är den biotekniska fasen som dominerar i Zero K går det att hitta spår av de andra faserna. The Convergence förändrar inte bara de nedfrusna subjektens kroppar utan även deras medvetanden. Genom att nano-enheter planterar in lämpliga receptorer i de väntande hjärnorna, vilka har skilts från kropparna och placerats i särskilda hjärnkapslar, kan väntan på det nya livet användas till att ta emot, och i någon mån uppleva, allt från klassiska filmer och kanoniserad litteratur till filosofi och pornografi (72).

Organisationens ledare uppmanar också sina anhängare att vidga vyerna och tänka utanför ramarna: "Take the existential leap. Rewrite the sad grim grieving playscript of death in the usual manner” (76). Där finns således en anmodan att tänka på ett nytt sätt. Skillnaden mellan föreställningarna om en ny människa vid det förra sekelskiftet och det som sker i Zero $K$, är att subjekten som låter sig frysas ned är ovetande om vilka nya tankar de kommer att förses med. I stället för att aktivt utvecklas och lära sig att tänka nytt, överlåter de passivt sina medvetanden åt andra krafter, vilka i sin tur väljer vilka tankar som ska forma den eventuella framtiden.

The Convergence ger inte uttryck för planer på några omfattande, politiskt genomdrivna samhällsprojekt, däremot talas det om en framtida värld där allt kanske har kollapsat, och där de enda som kan garanteras en framtid är de utvalda, de som återuppstår ur ökenanläggningens underjordiska valv. I stället för att tro på politiska förändringar, ser man politiken som ett omöjligt sätt att uppnå några mål över huvud taget. Det existerande samhället ses som förlorat, men det utlovas en framtid där de återuppväckta kommer att klara sig. Samtidigt går det att i projektet ana ett eko av 1900-talets totalitära regimer, där ledarna strävade efter att kontrollera undersåtarna in i minsta detalj. De som ansluter sig till the Convergence lägger sin eventuella framtid helt i händerna på projektets ansvariga, de som säger sig vilja driva utvecklingen framåt mot en bättre och starkare sorts människa. Samtidigt vet de som låter sig frysas ned väldigt lite om vad detta kommer att innebära: vilka tankar, vilken tro och vilken trohet mot vem eller vad kommer att finnas i deras medvetanden den dag de återuppstår? Den totala kontrollen över de anslutna subjekten påminner starkt både om historiens totalitära stater och dystopiska fiktioner som 1984, med den skillnaden att det är frivilligt att ansluta sig till the Convergence. Att det i anläggningens ideologi och praktiker finns ekon av totalitarism är också något som Jeff noterar: ”I wondered if I was looking at the controlled future, men and women being subordinated, willingly or not, to some form of centralized command. [...] when does utilitarian become totalitarian” (146-147).

Tekniken är dock det mest framträdande i skapandet av den nya människan såsom detta är representerat i Zero K. Kroppar och medvetanden som skiljs från varandra, förnyas och förbättras för att så småningom återuppväckas till ett nytt liv är visioner som är beroende av tekniken. Den teknik som här används för att tillvarata det mänskliga medvetandet för tankarna till robotforskaren Hans Moravecs vision om uppladdade medvetanden i Mind Children: The Future of Robot and Human Intelligence (1988). Där argumenterar Moravec för att det i en nära framtid kommer att vara möjligt att ladda över ett mänskligt medvetande 
till en dator (Hayles 1999: 1). Från transhumanistiskt håll ses visionen om uppladdade medvetanden som ett eftersträvansvärt framtida scenario. Hur det skulle fungera, om medvetandet skulle vara icke förkroppsligat, eller om det skulle fungera som en sorts back-up till det förkroppsligade medvetandet, placerat på en hårddisk någonstans utifall att något skulle hända med originalhjärnan, finns det olika tankar om. Ett argument som framförs är att det skulle kunna vara ett sätt att bevara medvetandet för dem som förlitar sig på kryonik för att undslippa döden (http://hplusmagazine.com/transhumanist-faq/\#answer_29). Om det här någonsin kommer att bli möjligt eller ej råder det delade meningar om, bland annat för att det inte går att med säkerhet förutsäga en framtida teknikutveckling, men också för att ingen egentligen vet vad ett medvetande är, och om det ens är möjligt att skilja detta något från kroppen.

I Zero $K$ finns inga reservationer kring uppladdande av mänskliga medvetanden. Det är en del av processen i anläggningen, och kallas "the brain-edit” (238). När medvetandet avskilts från kroppen ska subjektet fortfarande ha en sorts medvetande: "You will have a phantom life within the braincase. Floating thought. A passive sort of mental grasp. Ping ping. Like a newborn machine” (238). Här exemplifieras den begreppsupplösning mellan människa och maskin som Hayles skriver om. I de delar av Zero K som utspelar sig i ökenanläggningen är denna upplösning närmast total. De mänskliga kropparna ska, som redan nämnts, förstärkas, utvecklas och förbättras medan de befinner sig i den kryoniska dvalan. All tänkbar teknik ska användas och den dag de eventuellt kommer att väckas till liv är frågan om de kommer att vara återuppväckta människor, nyfödda maskiner eller både och.

I Zero $K$ finns således spår av alla de tre varianter av nyskapandet av människor som Rosendahl Thomsen beskriver. Det som utmärker skeendena i romanen är att deltagarna är passiva och överlåter agensen för vilken riktning deras framtida kroppar och medvetanden ska ta till teknokraterna i the Convergence, samt att de frivilligt upplåter sina kvarlevor som råmaterial för dem som säger sig vara på väg att skapa en ny sorts människa.

Språk är ett återkommande tema i DeLillos författarskap. Enligt litteraturvetaren David Cowart tematiserar DeLillo språket på olika sätt i alla sina romaner (Cowart 2008: 151-152). Zero $K$ är inget undantag. I skapandet av den nya människan är språket centralt, då man inte nöjer sig med att skapa en ny, mer välutvecklad människa utan också arbetar för att förse henne med ett nyskapat språk. Till den arsenal av människor med olika sorters kompetenser som arbetar med framtidens människa i the Convergence hör också språkvetare:

There are philologists designing an advanced language unique to the Convergence. Word roots, inflections, even gestures. People will learn it and speak it. A language that will enable us to express things we can't express now, see things we can’t see now, see ourselves and others in ways that unite us, broaden every possibility (33).

Exakt hur ett nytt språk ska ge framtidens människor bättre möjligheter att uttrycka sig och att förstå varandra framgår inte. Under Jeffs strövtåg i den ödsliga anläggningen möter han en äldre man, Ben-Ezra, den enda av anläggningens företrädare som bryter anonymiteten och presenterar sig med namn. Enligt Ben-Ezra ska det artificiella språket läras in av vissa, medan andra ska få det inplanterat medan de befinner sig i kryonisk dvala. Ben-Ezra hyllar språket för dess exakthet, för den förmåga det kommer att ha att uttrycka saker som aldrig, med de befintliga språken, har kunnat uttryckas. Han beskriver det som: "[a] system that will offer 
new meanings, entire new levels of perception” (130). Språket ska närma sig matematikens precision, och det kommer att sakna liknelser, metaforer och analogier (130). Ett språk som på det viset berövas ett bildspråk låter inte som ett språk som kan generera rikare upplevelser, utan det låter fattigt och begränsat. Att bildspråk behövs för att förmedla upplevelser och intryck visas också i romanen genom att det i de olika tillbakablickarna, och även i de delar som utspelar sig i New York finns gott om bildspråkliga inslag. Ett av många exempel är när Ross målande liknar sig och Artis vid ett par tonåringar, som sparat och ramat in sina gamla tjurfäktningsbiljetter som minne av en resa till Madrid (150).

Det går således att dra slutsatsen att det nya språket som skapas i the Convergence inte är funktionellt vare sig för att beskriva det liv Artis och Ross har levt tillsammans, eller för att skapa en litterär text som Zero K. Frågan är då vad det ska vara bra för. Ett språk som är så exakt att det inte behövs några bildspråkliga inslag för inte tankarna till fördjupade upplevelser, utan snarare till det förtryckande, begränsande Newspeak som finns i Orwells 1984. Där sysselsätter sig språkvetare, precis som hos the Convergence, med att konstruera ett nytt språk. Syftet med Newspeak är att skapa ett exakt språk som inte består av mer än ett sätt att säga en specifik sak, och genom att begränsa de språkliga möjligheterna omöjliggörs också det fria tänkandet: "the whole aim of Newspeak is to narrow the range of thought" (Orwell 1977: 52). Även om transhumanisterna i romanen beskriver det nya språket som någonting som kommer att berika de enskilda subjektens framtida upplevelser är det svårt att inte tänka att det är precis tvärtom, att det nya språket i stället kommer att göra dem fogligare och lättare att styra. Här, precis som i föregående avsnitt, framträder de auktoritära inslagen i ideologin bakom the Convergence: ledarna lovar sina undersåtar evigt liv i utbyte mot att de upplåter sina kroppar och sina medvetanden åt krafter de inte vet någonting om. De går dessutom med på att i sitt framtida, återuppväckta tillstånd överge det språk de har när de dör, eller fryses ned, det språk med vilket de fritt kan tänka och uttrycka tankar och känslor. Det posthumana tillstånd dessa subjekt kommer att befinna sig i kommer att vara starkt kringskuret, och det nya språket torde bidra till detta.

Där transhumanister drömmer om en tekniskt förstärkt posthuman kropp, hoppas kritiska posthumanister i stället att framtiden ska föra med sig nya sätt att vara människa på. I Braidottis vision om en ny människa ingår en större ödmjukhet inför vår plats i universum. Hon förespråkar en ny sorts subjekt, ett posthumant sådant, som är relationellt till sin karaktär och bland annat hämtar näring ur ekologism och miljörätt. Det posthumana subjektet har enligt Braidotti en stark känsla av samhörighet, också med de icke mänskliga subjekten. För detta krävs ett avståndstagande från dagens självcentrerade individualism (Braidotti 2013: 48).

Av detta finns inget i den värld som skildras i Zero $K$, utan i stället är det just individualismen som fokuseras. Det är de enskildas rätt att slippa dö, eller i alla fall att betala för förhoppningen om fortsatt liv efter döden, som driver verksamheten vid the Convergence. När Jeff rör sig genom anläggningen stannar han emellanåt framför stora skärmar som sänks ned från taket. På dessa visas filmer föreställande olika katastrofer. Skärmarna fylls av människor som i panik flyr undan bland annat översvämningar, skogsbränder och orkaner. Inte alla men många av katastroferna som visas är naturkatastrofer som skulle kunna relateras till vår tids klimathot, ett exempel på att vi lever i antropocen. Bakom the Convergence finns stora mängder kapital som kommer från mäktiga bidragsgivare: "[i]ndividuals, foundations, 
corporations, secret funding from various governments by way of their intelligence agencies” (33-34). All denna rikedom skulle ha kunnat investeras i något annat än en anläggning där vetenskapligt kunniga försöker skapa en ny sorts, odödlig människa. Till exempel hade den kunnat investeras i forskning för att hejda klimatförändringarna, eller för att på andra sätt göra världen till en bättre plats. Det är dock inte aktuellt eftersom människorna bakom the Convergence redan ser världen i dess nuvarande form som förlorad. När Ben-Ezra samtalar med Jeff radar han upp argument för varför världens nuvarande tillstånd inte kommer att förbättras, utan försämras: den hotande klimatkatastrofen, bristen på vatten, risken för pandemier, biologisk krigföring och mycket annat (126-127). I stället för att försöka bromsa upp i den utförsbacke världen befinner sig i, vill the Convergence skapa en ny människa, som med hjälp av tekniska förstärkningar är rustad att leva för evigt även i en fysiskt förändrad verklighet. När en av ledarna talar inför nya bidragsgivare berättar han vad de ska vakna upp till: "a renewed environment, a ravaged environment" (75). Det är i denna ödelagda framtida värld de kryoniskt bevarade kropparna så småningom ska återuppväckas, kapabla att leva sina eviga liv i en miljö som mest sannolikt är förstörd. Här finns således ett tydligt fokus på individen, det fokus Braidotti med flera anser att vi människor måste släppa, om världen någonsin ska bli en bättre plats. Att rädda världen är ointressant för transhumanisterna i Zero $K$, i stället vill de rädda de få som har råd till ett liv i en framtida förstörd värld. DeLillo låter emellertid inte den här världen, där de rika räddar sig undan katastrofen, framstå som speciellt lockande. Den verklighet som finns i ökenanläggningen är anonym, kall och glädjelös. Det är en existens utan innehåll.

Den kritiska posthumanismen handlar förvisso inte bara om nya sätt att tänka, utan är också inriktad på det kroppsliga. Donna Haraways cyborg-figur från 1980-talet är en grundstomme i dagens diskussioner om den posthumana kroppen. En cyborg är en organism som består både av biologisk vävnad och syntetiska delar. Enligt såväl Haraway och Hayles som Braidotti är kroppen central då vi primärt är kroppsliga varelser. Haraway anser att vi i praktiken redan är cyborgs eftersom vår mänskliga existens på alla plan, såväl praktiska som idémässiga, är sammanflätad med teknologier av olika slag (Haraway 2004: 8). Braidotti och Hayles delar hennes uppfattning om att vi redan är sammansmälta med tekniken, även om de beskriver det som att vi redan är posthumana subjekt. Det är viktigt att se att de kritiska posthumanisterna, trots betoningen på gränsupplösningen mellan natur och kultur, inte på något vis är teknik- och framstegsfientliga. Tvärtom, de bejakar den tekniska utvecklingen, men problematiserar samtidigt de etiska problem denna för med sig.

Att vi redan är posthumana subjekt innebär inte en slutpunkt för mänskligheten, utan bara slutet för en specifik uppfattning om vad det innebär att vara människa: "a conception that may have applied, at best, to that fraction of humanity who had the wealth, power and leisure to conceptualize themselves as autonomous beings exercising their will through individual agency and choice” (Hayles 1999: 286). Det här är kärnan i kritiken av humanismens människouppfattning: den gäller endast vissa utvalda. På samma sätt är det med det transhumanistiska projektet i Zero $K$. Det är inte för alla, utan bara för dem som har råd. Detta stämmer väl överens med hur Braidotti beskriver verkligheten i dag: bio- och gentekniken har kapitaliserats, vilket i praktiken innebär att livet självt har varufierats (Braidotti 2013: 59). Livet är definitivt varufierat i Zero K, i och med att människor tror sig 
kunna köpa sig fria från döden. I priset ingår också att den egna kroppen successivt förbättras medan den försänkt i kryonisk dvala inväntar framtiden.

Emellertid finns det också andra kroppar i Zero K, kroppar som kan läsas som en kontrast till de tekniskt modifierade kropparna. Jeffs flickvän Emma arbetar i en skola för barn med olika funktionshinder. Vid ett tillfälle besöker Jeff Emmas arbetsplats. Han ser då hur barnen trots sin bristande perfektion lever, fungerar och skrattar (189-191). Skolbarnen är detaljerat beskrivna på ett sätt som kontrasterar det artificiella hos the Convergence.

Sammantaget går det att hitta en hel del samhällskritiska inslag i relation till skapandet av en ny människa i Zero K. Romanens transhumanistiska projekt framstår som tvivelaktigt, i och med att det innehåller en stor del auktoritära inslag. Utöver detta är det tydligt att Zero K skildrar en ojämlik värld, där de allra mest förmögna hellre ser till sig själva än använder sin rikedom för att förbättra världen. Zero $K$ iscensätter frågor som tangerar Braidottis resonemang om hur bio- och genteknik i dag har varufierats, i stället för att användas för att göra tillvaron bättre för alla, såväl mänskliga som icke-mänskliga.

\section{Döden}

Den tid vi lever i karakteriseras av en paradoxal inställning till döden. Döden har samtidigt både skjutits längre ifrån oss, och kommit närmare. Den har förflyttats ifrån oss genom att vi kan leva allt längre då alltfler sjukdomar kan botas. Döden har också avlägsnat sig från individen i och med att teknikutvecklingen har frambringat nya, skrämmande effektiva sätt att döda. I dag går det att föra krig på distans med hjälp av drönare, vilket gör att den fysiska döden förflyttas längre bort, också från den som dödar. Samtidigt har döden också kommit närmare. Braidotti konstaterar att människor knappast i någon tid har oroat sig för så mycket som är relaterat till att dö. Handlar det inte om rynkor och skräcken för att åldras, det vill säga att varje dag komma en dag närmare den sista, så handlar det om oron för pandemier, terrordåd och andra okontrollerbara faktorer som kan hota våra kroppars fortsatta existens (Braidotti 2013: 112-113).

The Convergence verksamhet bygger på idén att döden är någonting den kapitalstarka har rätt att besegra. Döden är någonting som ska övervinnas: "[a]t some point in the future, death will become unacceptable even as the life of the planet becomes more fragile” (66). Olika former av livsförlängning med hjälp av tekniska åtgärder är en del av det transhumanistiska tänkandet. Det kan handla om allt från att fördröja åldrandet till en strävan efter odödlighet. Den transhumanistiska diskursen om livsförlängning kan ses som en slags modern utopi (Dickel och Frewer 2014: 119). Även om få i dag planerar att efter döden låta sig placeras i en kryonisk kapsel är olika mildare varianter av livsförlängning i dag vardag. Tänk bara på alla föryngrande hudkrämer och kosttillskott som på olika sätt lovar att fördröja effekterna av åldrande. Att vilja skjuta upp döden är en del av vår kultur. De som väljer att försöka göra det med hjälp av kryonik är dock förhållandevis få. Även om det i dag ses som en lite makaber idé i tranhumanismens utkant förekommer det, och utvecklingen inom nanotekniken ses av många som ett steg närmare att kunna återuppväcka döda kroppar (Bostrom 2005: 10). 2014 hade den amerikanska anläggningen Alcor drygt 100 nedfrusna kroppar i sina tankar, och över 900 personer som betalat för att efter döden få sin kropp placerad i en kryonisk tank 
(Dickel och Frewer 2014: 123). Det innebär att en del av det som sker i Zero K är verklighet redan i dag.

Zero $K$ är en roman som präglas av döden. Det är inte bara i ökenanläggningen som människor dör. I analepser skildras hur Jeffs mor Madeline dog, där kontrasten mellan hennes och Artis död blir påtaglig. Madeline dog av ett slaganfall, och hon dog hemma i sin säng med en vän och Jeff intill sig. Artis död är planerad, och hon dör långt bort från sin hemmiljö omgiven av främlingar i vita rockar. Madelines liv skildras med hjälp av detaljer, ofta till synes oviktiga sådana, men tillsammans målar de upp en bild av människan Madeline. Även beskrivningarna av hennes död är förankrad i detaljer: "The neighbour, the cane, the bedspread” (203). Artis är mer diffust gestaltad. Hon är vacker och intelligent, och allvarligt sjuk, men det är svårt att få grepp om henne som person. Hon framstår mer som en idealbild för Ross att dyrka än som en verklig människa. Hennes död, som i praktiken innebär att hon blir dödad av personalen i the Convergence, framstår som vag bland annat för att hennes anhöriga inte vet när exakt hon dör (139). Den process hennes kropp utsätts för är också så teknifierad att den känns avlägsnad från den kroppsliga döden. Den blir därför ogreppbar och svår att relatera till.

Även Emmas adoptivson Stak dör. Han försvinner, och det visar sig senare att han återvänt till Ukraina, det han land han föddes i, för att delta i det där pågående kriget. Strax innan Jeff lämnar the Convergence för andra gången ser han Stak i en av anläggningens videoinstallationer. Skärmen framför Jeff fylls den här gången inte av naturkatastrofer, utan av krig. Otäcka bilder av förstörda städer och söndersprängda kroppar följs av närbilder på soldater. Plötsligt ser Jeff att en av dem är Stak, och på filmen får Jeff se hur Stak blir träffad av flera kulor och dör. Stak som fortfarande är tonåring och borde ha haft ett långt liv framför sig dör i stället en meningslös död i en meningslös konflikt. Genom att varken konflikten eller Staks motiv för att delta i den förklaras betonas bristen på mening. Här pekar DeLillo på det orättvisa i att vissa dör i förtid i krig, medan andra i stället kan köpa sig rätten till ett längre liv.

Döden handlar emellertid inte bara om mänsklig död. Allra minst i dag när ett stort antal arter hotas av utplåning till följd av mänskligt handlande. En del i Braidottis posthumanistiska tänkande om döden handlar om att försöka tänka bortom gränsen mellan liv och död. I stället för att leva med döden ständigt lurande runt nästa hörn vill hon se döden som någonting som är inskrivet i vår existens redan från början. Att i stället tänka sig varje subjekt, mänskligt såväl som icke-mänskligt, som en del i en kontinuitet av liv och död kan enligt Braidotti leda till ett mer etiskt, rättvist och ödmjukt sätt att existera. Hon är dock väl medveten om svårigheterna att tänka bortom det egna jaget, att tänka sig livet som viktigt vare sig man själv är en del av det eller ej. Hon betonar ändå vikten av att sträva dithän: "Life is passing and we do not own it; we just inhabit it, not unlike a time-share location” (Braidotti 2013: 133). Det här innebär inte att Braidotti är motståndare till en utveckling där vi successivt botar fler sjukdomar och således kan leva längre. Emellertid anser hon att detta är någonting som bör komma alla till godo, inte bara de välbeställda mänskliga subjekten. Det är en fråga om rättvisa. Det tänkesättet saknas hos the Convergence. I stället är det en självklarhet att rätten att slippa dö inte är för alla: ”Life everlasting belongs to those of breathtaking wealth” (76). 
Det finns som synes stora skillnader i synen på döden, där ytterligheterna utgörs av de som anser att vi ska förlika oss med vår dödlighet och även tänka bortom det enskilda subjektets död, och de som anser att döden är någonting som människan inom en snar framtid kommer att besegra.

En annan skiljelinje går mellan de som tror att medvetandet är förkroppsligat, och de som tror att det bara består av information som lika väl kan placeras i ett annat medium än den mänskliga kroppen. Även om det inte är en skillnad i synen på döden i sig, är det relevant i förhållande till den kryoniska verksamhet som bedrivs i Zero K, eftersom denna förutsätter en tro på möjligheten att skilja på kropp och medvetande.

Mellan romanens båda huvuddelar finns en kort passage med titeln Artis Martineau. Där skildras hur det som finns kvar av Artis medvetande letar efter spillrorna av den egna identiteten. Eller så är det eventuellt Jeff som föreställer sig det hela, det är lite oklart. På en av romanens sista sidor tänker Jeff på Artis, och försöker, i strid med sin egen övertygelse (han tror att hon är fullständigt död), föreställa sig hur hon upplever någon sorts medvetenhet: "[t]hen I try to imagine an inner monologue, hers, self-generated, possibly nonstop, the open prose of a third-person voice that is also her voice, a form of chant in a single low tone" (272). Det här beskriver väl dessa sidor, fokaliserade genom resterna av Artis medvetande. Det innebär att DeLillo låter det vara oklart om det som sker hos the Convergence lyckas eller ej. I romanen finns egentligen ingenting som visar att vetenskapsmännen i öknen har lyckats med något av allt det de säger sig kunna göra. Kanske är de döda kropparna i underjorden ingenting annat än döda kroppar, med lika liten chans att återuppstå som vilka döda kroppar som helst.

Det står läsaren fritt att välja om avsnittet om Artis medvetande ska tolkas som någonting Jeff föreställer sig eller som någonting som verkligen sker. Oavsett vilket är det obehaglig läsning. På fragmentarisk prosa trevar sig jaget fram, på jakt efter någon sorts mening. Texten är skriven i omväxlande första och tredje person, där jaget både berättar och försöker föreställa sig vad, var och varför det är. Det verktyg den kroppslösa rösten använder sig av är språket: "[s]he knows these words. She is all words but she doesn't know how to get out of words into being someone, being the person who knows the words” (157). Rösten har ett språk, men avskuret från allt annat, kropp, materia och sammanhang, saknar orden mening, de är bara ord. Det som en gång var Artis vet inte längre vad det är: "[a]re the words themselves all there is. Am I just the words” (158). När rösten söker ett sammanhang hittar den inget alls. Den försöker lyssna, men hör bara sig själv och den söker efter sin kropp utan att känna den. Jaget strävar efter att hitta något att fästa orden vid, men utan att lyckas. Det som en gång var Artis består nu bara av ord, men orden saknar mening eftersom de inte relaterar till något.

En av många som vare sig tror på, eller lockas av, tanken på ett kroppslöst medvetande är Hayles: "how could anyone think that consciousness in an entirely different medium would remain unchanged, as if it had no connection to the embodiment?” (Hayles 1999: 1). Naturligtvis går det inte att säga hur det skulle vara att separera medvetandet från kroppen. Emellertid går det att föreställa sig, och så som DeLillo föreställer sig det är det lätt att hålla med Hayles. Det som skildras är inte lockande. Det är ett fragment av en tillvaro, som saknar förankring i både tid och rum. Att det kroppslösa medvetandet som ska bevaras eventuellt kan komma att uppleva en oändlig ensamhet är ingenting det hymlas med. Tvärtom, det 
målas nästan ut som någonting positivt, som ett tillstånd den som är tillräckligt stark kan se fram emot. Ett slags rent tillstånd där alla masker och förställningar har kastats. Samtidigt varnar ledarna för ensamheten, och väcker frågan om vad jaget är: "[t]he self. What is the self? ... But are you anything without others?” (67).

I Zero $K$ är det inte bara för de kroppslösa medvetandena som språket är nödvändigt för att skapa mening. För Jeff är orden avgörande när det gäller att ge innebörd åt händelser, speciellt för att förstå det som händer i den artificiella, anonyma ökenanläggningen, och alla namnlösa människor som finns där. Endast en av alla som skymtar förbi namnges och det är Ben-Ezra. De levandes existens i ökenanläggningen påminner delvis om det avskilda medvetandets. Eftersom de inte presenteras med namn, ingenting berättas om vilka de är, var de kommer ifrån och vilka de är i förhållande till resten av världen, förblir de anonyma. När Jeff rör sig i korridorerna namnger han för sig själv olika människor han möter. Han fantiserar ihop bakgrundshistorier åt dem, vilket ger dem en sorts fiktiv existens i relation till resten av världen. Det är så Jeff skapar mening i tillvaron och försöker göra det obegripliga, faderns beslut att avsluta sitt liv i förtid i hopp om att väckas till liv i framtiden, begripligt.

Jeff är dock inte ensam om att hitta på namn. Även hans far har gjort det. Efter att ha fötts som Nicholas Satterswaite bytte han så småningom till Ross Lockhart, ett namn han ansåg passa bättre för den framgångsrika man han avsåg att bli (81-82). Språkets, och namns betydelse är återkommande i DeLillos romaner. I The Body Artist (2001) pekar DeLillo på behovet att veta var man är, och att också ha ett namn på var man är, för att förstå vem man är (Cowart 2008: 156-157). Detta gäller också i Zero K. Artis medvetande söker efter resterna av det egna jaget, men utan möjlighet att placera den egna existensen i tid eller rum förblir det ogreppbart.

För det posthumana relationella subjekt Braidotti ser som önskvärt är språket viktigt. Det posthumana subjektet som ska vara förankrat i omgivningen, kunna kommunicera över olika sorters gränser och förstå sin egen plats i en helhet i vilket både det mänskliga och det ickemänskliga ingår behöver språket (och antagligen fler än ett) som verktyg (Braidotti 2013: 49 och 82). Hos the Convergence berövas subjekten de språk de har med sig, och de språkliga rester som finns kvar räcker inte för att skapa mening för de sparade medvetandena, eftersom det inte finns någonting att relatera till. Det finns inga detaljer att fästa orden vid, vilket gör dem meningslösa. För Jeff däremot är det tydligt att språket fungerar meningsskapande, eftersom han lättare förstår sin far när han namnger saker och ting som har med faderns förtida död och nedfrysning att göra. Detta stämmer väl med Braidottis resonemang om relationella subjekt, eftersom det i DeLillos text är de subjekt som med hjälp av språket kan relatera till sin omgivning som hittar mening.

Att tro på ett liv efter döden är ingenting nytt, och tron är det som framstår som viktigast för Artis och Ross. Det finns som redan nämnts ingenting som säger att det som görs hos the Convergence kommer att lyckas. Trots det tror Artis och Ross att kryoniken ska göra dem odödliga, på samma sätt som människor som söker stöd i religiösa föreställningar om livet efter detta. Inte ens Ross förnekar att tron är central: "Faith-based technology. That's what it is. Another god. Not so different, it turns out, from the earlier ones. Except that it's real, it's true, it delivers” (9). Att tro att just den egna religionen är den rätta, den som till skillnad från andra irrläror är den som verkligen kan leverera är heller inte nytt. 
Enligt Braidotti har religiösa föreställningar i olika former successivt stärkt sin ställning sedan 1970-talet. Hon beskriver detta som den post-sekulära vändningen. Från att världen blev alltmer sekulariserad som en följd av att vetenskap kunde förklara det som tidigare bara kunnat förklaras i ljuset av en gudomlig makt, har det vänt och människor tror allt mer. Inte bara på organiserad religion utan på allt möjligt (Braidotti 2013: 31-32). Transhumanismen, som bygger på den rationella humanismens sekulära vetenskapstro, har emellanåt religiösa undertoner. Bland annat finns en stark tro på en oupphörlig teknikutveckling. Väntar man bara tillräckligt länge kommer allt till slut att vara möjligt, också evigt liv (Dickel och Frewer 2014: 125). Det är detta som ligger bakom tron på att kryoniskt bevarade kroppar kommer att kunna återuppväckas. Frågan är inte om, utan när. Det innebär att det trots betoningen av det sekulära också kan ses som en sorts tro. Hos Ross är tron stark, då han är övertygad om att han någon gång i framtiden kommer att återförenas med Artis.

Alla som finns $i$ the Convergence anläggning är emellertid inte troende. Jeff har flera samtal med en man som han för sig själv kallar munken. Trots att munken är klädd i munkkåpa, ägnar sina dagar åt att tala med de som ska dö och har ett förflutet i olika religiösa sekter är han själv inte troende. Han tror i stället att döden betyder slutet, och han har heller ingen längtan efter att leva för evigt: "I want to die and be finished forever. [...] What's the point of living if we don’t die at the end of it” (40). Munkens sätt att se på döden har mer gemensamt med Braidotti än med transhumanismen i och med att han ser livet som något han själv är en del av för att sedan lämna. Kanske kan munkens närvaro hos the Convergence tolkas som ett uttryck för komplexiteten i vår tids förhållande till tro. Det är inte säkert att den som framstår som religiös alltid tror mer än den som säger sig förneka en högre makt.

Det går också att hitta andra likheter med religiöst tänkande i Zero K. Bokens transhumanister strävar efter att rädda de utvalda undan en hotande katastrof. Detta kan tolkas som en parallell till Bibelns berättelse om Noas ark (1 Mos 6-8). Där säger Gud till Noa att han ämnar förgöra alla människor eftersom de har fyllt jorden med våld. Han tänker: "förgöra både dem och jorden” (1 Mos 6:13-14). Ben-Ezra talar om jorden som en plats som är på väg att gå under till följd av att mänsklig ondska och oaktsamhet har lett till terrorism, krig och klimatkatastrofer. Uppgiften för de som bevaras i de kryoniska kamrarna är att befolka den framtida jorden, efter katastroferna (126-127). Detta kan ses i analogi med hur Noa i arken räddar de som senare ska befolka jorden efter översvämningen. Skillnaden är att där Bibelns Gud uppmanade Noa att utöver sin familj ta med ett par av varje art som lever på jorden, bryr sig romanens transhumanister bara om människor, och dessutom bara förmögna sådana. Det transhumanistiska projektet i Zero $K$ kan tolkas som en senkapitalistisk version av Noas ark, där det avgörande för vem som har rätt att leva vidare är mängden kapital. Alla jordens andra arter som redan nu dör ut i skrämmande hög takt är det ingen hos the Convergence som bryr sig om. Om världen betraktas ur ett kritiskt posthumanistiskt perspektiv där livet är någonting som pågår oavsett de enskilda mänskliga subjektens existens ter sig Bibelns version av räddning undan katastrofen som ett bättre alternativ än det som presenteras av transhumanisterna i Zero $K$.

Frågan återstår dock om dessa genuint tror att de i framtiden kommer att återuppväckas. Kanske är anläggningens katastrofbeständiga kamrar ingenting annat än ett högteknologiskt mausoleum där de döda kropparna kommer att bevaras i evighet. Att vara redo att dö innebär inte att man är redo att försvinna som en av ledarna säger (74). Att välbeställda, 
framgångsrika människor förbereder sig för döden genom att se till att det finns en imponerande gravplats för dem är ingenting nytt. Detta vet Artis som en gång ägnade sig åt att gräva ut forntida gravar nära den plats hon själv nu valt ut som sin sista viloplats. Det är också så Jeff i slutet av romanen tänker sig de underjordiska kamrarna hos the Convergence: "[i]t was a form of visionary art, it was body art with broad implications. [...] Archeology for a future age” (256).

\section{Avslutande diskussion}

Det som skildras i Zero $K$ kan tolkas som en skrämmande framtidsvision, men det finns också likheter med dagens verklighet. Även om formerna inte är identiska med förhållandena i Zero $K$, är det ändå en realitet att mängden kapital avgör vem som ska få ta del av tekniska framsteg som på olika sätt kan hjälpa oss till ett längre, tryggare och friskare liv. Det är också en realitet att detta ofta sker på bekostnad av världens mindre lyckligt lottade: fattiga människor, djurliv och miljö. Att denna bristande omsorg på sikt riskerar att få katastrofala effekter även för den välbeställda delen av mänskligheten är knappast okänt för någon längre. Den snabba utvecklingen inom bio-, gen- och nanoteknik ställer krav på oss människor när det gäller hur vi ska förhålla oss till en alltmer föränderlig verklighet. Många av oss önskar förhoppningsvis att teknikutveckling ska komma världen till godo på ett rättvist och etiskt hållbart sätt, både avseende de mänskliga och de icke-mänskliga subjekten.

Transhumanisterna i DeLillos roman har emellertid inga betänkligheter när det gäller att satsa sitt kapital på drömmen om det egna jagets fortlevnad. Världen i stort ses som förlorad, och det gäller att rädda inte vad som räddas kan, utan de rika. Utifrån romanens starka fokus på de kapitalstarkas hybris när det gäller att skaffa sig själva fördelar i stället för att satsa på de omställningar som är nödvändiga för en värld i kris, tolkar jag Zero K som starkt kritisk till vår tids tilltagande ekonomiska ojämlikhet. Denna ojämlikhet blir inte mindre påtaglig i en tid när tekniska genombrott snabbt förändrar villkoren för människans existens. Det är talande att den förmögenhet Ross satsar på ett projekt han hoppas ska ge evigt liv har skapats genom att profitera på naturkatastrofer. Vissa av dessa har eventuellt orsakats av mänskliga ingrepp i jordens ekosystem och geologi. Braidottis kritiskt posthumanistiska vision att teknikutveckling ska komma alla tillgodo finns inte i Zero $K$, och även Kurzweils transhumanistiska föreställning om att teknikutveckling per automatik ska leda till förbättringar för allt och alla lyser med sin frånvaro. Romanens transhumanister ser det i stället som naturligt att det alltid kommer att finnas andra, sådana som lämnas att dö i en döende värld. Att det skulle finnas ett värde i att försöka rädda djur och natur nämns inte. Det här kan relateras till transhumanismens syn på människan som exceptionell. Förvisso finns inom transhumanismen också de som anser att teknisk förstärkning ska kunna gagna fler än de mänskliga subjekten, men då handlar det som regel om djur, cyborgs eller intelligenta maskiner som har nått en intelligens- och känslomässig utvecklingsnivå som gör dem människolika (More 2013: 13).

Genom att satsa på att skapa en ny människa som kan överleva i en förstörd värld, i stället för att satsa på att rädda världen för dess egen skull drar romanens transhumanister detta resonemang till dess yttersta spets. Den humanism som kritiseras från ett kritiskt posthumanistiskt håll för att dess definition av vem, eller vad, som ges en subjektsposition är 
alltför begränsad drivs också till det yttersta i Zero K. Detta i och med att det inte bara är de icke-mänskliga subjekten som exkluderas från den tänkta framtiden, utan också merparten av de mänskliga. Sedan återstår förstås frågan om det de rika tillskansar sig i Zero $K$ är någonting att sträva efter.

I de planer som finns i romanens transhumanistiska projekt ingår att de kryoniskt bevarade individerna ska stöpas om till någonting nytt innan de återuppväcks. Det ska skapas en ny sorts människa, anpassad för framtiden. Frågan är emellertid om dessa fortfarande kommer att kunna förstås som mänskliga. I Zero $K$ sägs att framtidens återuppväckta individer kommer att vara som nyfödda maskiner. Detta är en extremvariant av den gränsupplösning mellan människa och maskin som Hayles skriver om. Hon anser att uppluckringen av gränser kan ha en frigörande potential, i och med att människovarandet inte längre skulle vara lika begränsat. I romanen är det dock svårt att se någonting sådant, eftersom de kryoniskt bevarade har minimalt med inflytande över vilka, eller vad, de kommer att vara när de väcks till liv igen. Ross och hans gelikar satsar enorma summor för att de och deras älskade kanske ska få en fortsättning på livet också efter döden. Hur den fortsättningen kommer att se ut har de inget inflytande över. När de väl har låtit sig försänkas i den kryoniska dvalan har de lämnat ansvaret till ett ledarskikt vars planer de vet ytterst lite om. Det är lätt att se de auktoritära dragen i den verksamhet the Convergence bedriver. Skapandet av en ny sorts människa, med ett tillhörande nytt begränsande språk, där individerna själva inte har kontroll över vilka tankar, lojaliteter eller känslor som kommer att placeras i deras slumrande medvetanden är skrämmande. Det de investerar i är drömmen om en framtid i utbyte mot att de ger upp sin frihet i denna eventuella framtid. De enskilda subjektens avsägande av kontroll kan tolkas som en parallell till vår tids framväxande auktoritära politiska krafter. Företrädare för dessa lovar ofta att väldigt mycket ska bli bättre, utan att säga hur, om de bara får tillräckligt mycket makt till sitt förfogande. Alla delar som ingår i hur den nya människan ska skapas i romanen förutsätter deltagarnas passivitet.

Den dag de kryoniskt bevarade väcks till liv igen kommer de inte att vara desamma som de var när de dog sin första död. Kanske är de fortfarande människor, och kanske är de posthumana kroppar som är övervägande maskiner. Deras medvetanden kommer att vara förändrade till oigenkännlighet, med ett nytt språk och nya inplanterade tankar och känslor. Eftersom det innebär att de inte längre kommer att vara desamma är frågan vad som egentligen är poängen. Om Ross och andra miljardärer i Zero $K$ i stället satsade sina resurser på att stoppa klimatförändringarna skulle det kunna ha samma effekt, nämligen att det i framtiden skulle finnas liv på jorden. Ross och Artis skulle inte finnas kvar, men det skulle de inte göra om deras transhumanistiska dröm förverkligades heller, eftersom de skulle vara någonting annat. Men det skulle finnas liv. Att värdesätta livet oavsett vems liv det handlar om är en central del i ett kritiskt posthumanistiskt tänkande om livet och döden. För att det ska vara möjligt krävs att synen på människans exceptionalism överges, och det krävs också att dagens fokus på individen lämnas därhän. Att Ross och Artis inte lägger pengarna på något som kan komma världen som helhet till godo hänger samman med att de båda är övertygade inte bara om att människan som art är exceptionell, utan om att de som individer är det. I kraft av sin rikedom är de speciella, och förtjänar därför att få finnas kvar. Ett starkare fokus på individen går knappast att hitta. 
Att Ross lämnar över sin förmögenhet till transhumanisterna i öknen handlar primärt om tro, om en liten gnutta hopp om att just han och Artis kommer att få vara en del av framtiden i någon form. Även om det i romanen hävdas att det här till skillnad från traditionell religiös tro är på riktigt, det här en tro som verkligen levererar evigt liv, är det ändå tro det handlar om. Det finns ingenting i romanen som med absolut säkerhet styrker att någon någonsin kommer att kunna återuppväckas.

Ross och Artis tillhör en grupp som delar en gemensam tro på livet efter detta för vissa utvalda. I andra religioner kan det vara goda handlingar som avgör vem som ska få nyckel till himmelriket. Här handlar det i stället om pengar. Nycklarna till himmelriket är till salu, och de är dyra.

Syftet med artikeln var att undersöka hur post- och transhumanistiska teman är representerade i Zero $K$, och hur dessa sedan kan kopplas samman med romanens samhällskritiska inslag. Romanens post- och transhumanistiska teman är framförallt representerade som en extrem transhumanistisk utopi, med starka auktoritära undertoner. Det framgår också tydligt i hur hög grad tron på evigt liv medelst tekniska hjälpmedel liknar traditionell religion, vilket är förenligt med Braidottis beskrivning av vår post-sekulära tid.

De samhällskritiska inslagen i Zero $K$ är många. Framförallt läser jag romanen som kritisk till vår samtids individcentrering och starka fokus på kapital, men där finns också ett ifrågasättande av dagens ofta okritiska syn på utvecklingen inom bio- och genteknik. När möjligheterna blir större ökar också behovet av att diskutera både vad som är etiskt och vem som egentligen har rätt att dra ekonomisk nytta av upptäckter som berör livet i stort. Att livet försänkt i kryonisk dvala är gestaltat som skrämmande och meningslöst, går att se i relation till behovet att diskutera rätt och fel i förhållande till tekniska möjligheter. Att det i romanen uteslutande är de mycket rika som drar fördel av tekniska framsteg kan läsas som en kommentar till vår tids eskalerande ekonomiska ojämlikhet.

\section{Referenser}

Bibel 2000, tillgänglig på www.bibel.se.

Bostrom, Nick (2005), "A History of Transhumanist Thought”, i Journal of Evolution and Technology vol. 14: 1-25.

Braidotti, Rosi (2013), The Posthuman. Cambridge: Polity.

Clarke, Bruce och Rossini, Manuela (red) (2017), The Cambridge Companion to Literature and the Posthuman. Cambridge: Cambridge University Press.

Cowart, David (2008), "DeLillo and the power of language” i Duvall, John N. (red), The Cambridge Companion to Don DeLillo. Cambridge: Cambridge University Press.

DeLillo, Don (2016), Zero K. New York: Scribner.

Dickel, Sascha och Frewer, Andreas (2014), "Life Extension: External Debates on Immortality" i Sorgner, Stefan Lorentz och Ranisch, Robert (red), Post- and transhumanism: An introduction. Frankfurt: Peter Lang Publishing Group.

Duvall, John N. (2008), "Introduction: The power of history and the persistence of mystery" i Duvall, John N. (red), The Cambridge Companion to Don DeLillo. Cambridge: Cambridge University Press.

Foucault, Michel (2005) [1966], The Order of Things. London: Routledge.

Fukuyama, Francis (2002), Our Posthuman Future: Consequences of the Biotechnology Revolution. New York: Farrar, Strauss and Giroux. 
Haraway, Donna (2004) [1985], ”A Manifesto for Cyborgs: Science, Technology, and Social Feminism in the 1980s" i Haraway, Donna, The Haraway Reader. New York: Routledge.

Haraway, Donna J. (2008), When Species Meet. Minneapolis: University of Minnesota Press. Hassan, Ihab (1977), "Prometheus as Performer: Toward a Posthumanist Culture?”, Georgia Review Vol. 31, No. 4, s. 830-850.

Hayles, N. Katherine (1999), How We Became Posthuman: Virtual Bodies in Cybernetics, Literature and Informatics. Chicago: University of Chicago Press.

Kurzweil, Ray (2013), "Progress and Relinquishment” i More, Max och Vita-More, Natasha (red), The Transhumanist Reader: Classical and Contemporary Essays on the Science, Technology, and Philosophy of the Human Future. Chichester, Wiley-Blackwell.

More, Max, (2013), "The Philosophy of Transhumanism” i More, Max och Vita-More, Natasha (red), The Transhumanist Reader: Classical and Contemporary Essays on the Science, Technology, and Philosophy of the Human Future. Chichester, WileyBlackwell.

Orwell, George (1977) [1949], 1984. London: Signet Classics.

Osteen, Mark (2000), American Magic and Dread: Don DeLillo's Dialogue with Culture. Philadelphia: University of Pennsylvania Press.

Ranisch, Robert och Sorgner, Stefan Lorenz (2014), "Introducing Post- and Transhumanism” i Ranisch, Robert och Sorgner, Stefan Lorenz (red), Post- and Transhumanism: An Introduction. Frankfurt am Main: Peter Lang Edition.

Rosendahl Thomsen, Mads (2013), The New Human in Literature: Posthuman Visions of Changes in Body, Mind and Society after 1900. London: Bloomsbury.

Sundin, Bosse (2006), Den kupade handen: Historien om människan och tekniken, Andra utökade upplagan. Stockholm: Carlssons.

Transhumanist FAQ tillgänglig på http://hplusmagazine.com/transhumanist-faq/\#answer_20.

Wolfe, Cary (2010), What is Posthumanism? Minneapolis: University of Minnesota Press.

Åsberg, Cecilia (2012), ”Läskunnighet bortom humaniorans bekvämlighetszoner” i Åsberg, Cecilia, Hultman, Martin och Lee, Francis (red), Posthumanistiska nyckeltexter. Lund: Studentlitteratur.

Öhman, Marie (2015), Det mänskligas natur: posthumanistiska perspektiv hos Lars Jakobsson, Peter Høeg och Kerstin Ekman. Möklinta: Gidlund. 